\title{
Optimization of new beach nourishment concept for landowners with properties at acute risk
}

\author{
Per Soerensen, Danish coastal authority, pso@kyst.dk \\ Nils Drønen, DHI group, NKD@dhigroup.com
}

\begin{abstract}
MOTIVATION
In Denmark it is the landowners responsibility to get a permit for coastal protection and pay for it. On natural coasts without man made structure, a new concept consisting of a sandbuffer with a sleeping defence has been implemented on two locations.

The sandbuffer must ensure that the sleeping defence must be covered with sand at all time. The optimization of the sandbuffer is done numerically using Mike21 FM Shoreline Model, and by surveying the performance in Interreg project Building With Nature.
\end{abstract}

\section{PRICIPLE FOR CCOASTAL PROTECTION SCHEME}

On natural sandy coast in Denmark a coastal protection may not reduce the natural dynamics, change the coastal landscape or cause leeside erosion.

Therefore sand nourishment is the optimal solution in many ways, and it is the most cost effective. However some landowners wants additional safety if their house is very close to the cliff.

If a house is within 2 times the maximum dune face retreat during a very severe storm, one of the requirements for using revetments of rocks are met. Another requirement is that the revetment must be covered with sand at all time. Therefore a buffer of sand must be in place in front of the revetment covering it. To compensate for the morphological scales on the coast, the buffer of sand must extend the length of the revetment, both upstream and downstream.

\section{NUMERICAL MODELLING}

The Danish coastline are more than $7.300 \mathrm{~km}$ long and the erosion pressure and geology changes a lot. This implies a huge challenge for the coastal engineers designing and optimizing the sandbuffer.

To help two steps of numerical modelling has been undertaken. The first step has been to model the maximum dune face retreat under storm using Mike 21 $\mathrm{IG}$ and Xbeach.

The second step has been using Mike 21 FM Shoreline model to model the distribution and decay of a sandbuffer with different spatial parameters depending of the exposure of the coast. 16 calculations has been done for each degree of exposure. / where the nourishment is evenly distributed over the active coastal profile, 6 where the coastline orientation varies and 3 different layouts of the beach nourishment.

Design diagrams based on the result from the numerical simulations has been made for the expected lifetime of sand nourishments based on their length and relative volume. A exponential distribution

$$
\frac{V}{V_{0}}=e^{-K t}
$$

Fits the data well. $v / v_{0}$ is the relative volume, $t$ is time and $\mathrm{k}$ is a decay constant. A diagram for very exposed, exposed and less exposed coast has been constructed,

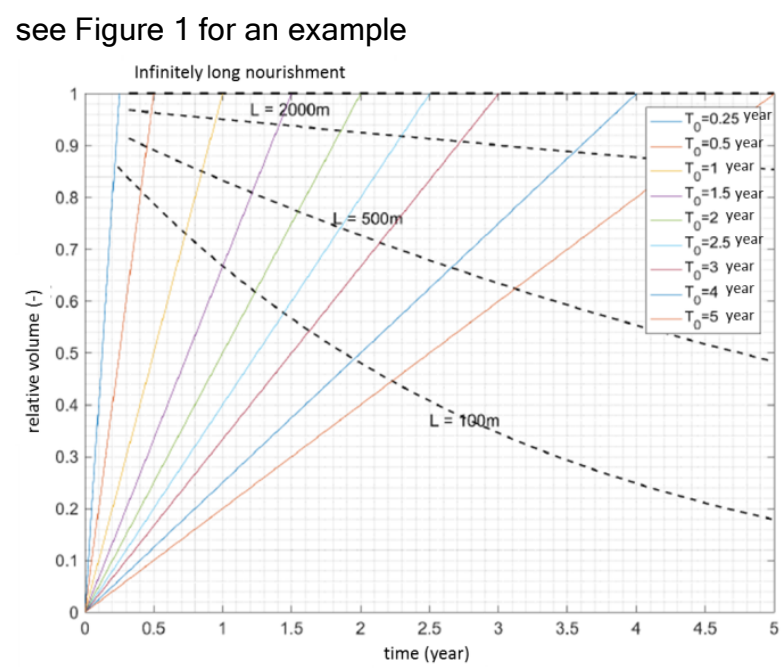

Figure 1 - Expected lifetime of nourishments with different lengths and relative volumes.

\section{PERFORMANCE MONITORING AND ANALYSIS}

Nature is very dynamic, and the active coastal profile is indeed. Therefore two different design of a sandbuffers with sleeping defense inside is currently been monitored to gain more knowledge. The surveys will be analyzed in the Building With Nature Interreg project and the design criteria for the sandbuffer and morphological scale will be evaluated and s adjusted if necessary.

The results from the numerical simulations and the results from the monitoring will be used to upscale the design of different sandbuffer nourishment schemes to a national level and will be included in national guidelines.

\section{REFERENCES}

Earnshaw, Madsen, Soerensen (2014), Analysis and modelling of extreme localized dune erosion events along Denmarks North sea high water dune barrier, Proceedings ICCE 2014

Drønen (2017), Guideline for sandfodring, Client report

Ries (2017), Building with nature, Numerical simulation of acute erosion under storm condition with Mike21 IG, Skodbjerge Denmark

Winter, Ruessink (2017), Sensitivity analysis of climate change impacts on dune erosion: case study for the Dutch Holland coast. SPRINGER 